\title{
Conscientious Objection, 'Proper Medical Treatment', and Professionalism: the Limits of Accommodation for Conscience in Healthcare
}

\author{
Mary Neal*
}

\section{Introduction}

In recent years there has been a marked increase in academic interest in the phenomenon of conscientious objection (CO) in healthcare. The resulting literature, which is already substantial and continually expanding, reflects a spectrum of opinion on the practice ranging from support through mere toleration to barely disguised (and occasionally open) hostility. Despite some forceful academic opposition, however, ${ }^{1}$ most scholars who engage with the issue recognise the appropriateness of accommodating $\mathrm{CO}$ at least to some extent. The usual way of explaining why it is necessary and/or desirable to accommodate CO involves citing the need to protect individuals from being obliged to violate their moral integrity in the course of performing their professional roles. The meaning of 'moral integrity' is itself the subject of detailed philosophical debate, ${ }^{2}$ and is not my focus in this chapter: here, I presuppose that 'a physician's interest in moral integrity is a very important interest

\footnotetext{
* School of Law, University of Strathclyde. I first presented the paper on which this chapter is based at 'Conscience in Law and Medicine: A Half-Day Symposium' at the Anscombe Bioethics Centre, Oxford on $12^{\text {th }}$ April 2018, and I am grateful to David A Jones, Toni Saad, and others who were present at that event for helpful discussion of the main themes. I would also like to thank my frequent co-author and collaborator Sara Fovargue of Lancaster University for our frequent (and often vigorous) conversations about conscience, including discussion of the themes explored in this chapter.

${ }^{1}$ See, eg J Savulescu, 'Conscientious Objection in Medicine' (2008) 332 British Medical Journal 294; U Schuklenk and R Smalling, 'Why Medical Professionals have no Claim to Conscientious Objection Accommodation in Liberal Democracies' (2017) 43 Journal of Medical Ethics 234; and A Giublini, 'The Paradox of Conscientious Objection and the Anemic Concept of "Conscience": Downplaying the Role of Moral Integrity in Healthcare' (2014) 24 Kennedy Institute of Ethics Journal 159.

2 Mark Wicclair's defence of the 'identity conception' of moral integrity in the healthcare context includes helpful discussion of a range of views: MR Wicclair, 'Conscientious Objection in Healthcare and Moral Integrity' (2017) 26 Cambridge Quarterly of Healthcare Ethics 7.
} 
that has substantial moral weight' ${ }^{3}$ and that the primary reason for accommodating and exercising $\mathrm{CO}$ is that we recognise the value of moral integrity and wish to respect and preserve it.

No-one supports an unlimited right to $\mathrm{CO}$, however; all of us who recognise the need to protect professionals against violations of integrity also recognise that we cannot simply allow each individual professional complete liberty to decide which parts of her role she will perform. A principal concern uniting writers across the spectrum of opinion, therefore, is the issue of limiting accommodation for conscience: which conscience claims, if any, do we regard as valid and wish to accommodate, and which do we wish to exclude, and what criteria can be used to tell between the two? Among sympathetic commentators, this concern has generated an ongoing discussion in which various suggestions regarding the appropriate parameters of $\mathrm{CO}$ are proposed and debated. At the sceptical/hostile end of the spectrum, it is claimed that it is impossible to defend $\mathrm{CO}$ in a limited way, so that allowing it inevitably opens the floodgates to an ever-increasing tide of refusals in the absence of any way of excluding those that are spurious. My argument in this chapter is a contribution to the sympathetic project of attempting to identify defensible parameters for $\mathrm{CO}$.

In any discussion of $\mathrm{CO}$, it is helpful at the outset to distinguish the latter practice from 'conscience' in the wider sense. Although there are various theories of what conscience is, and a range of suggested definitions, I understand conscience to be a faculty that enables us to direct, reflect on, and assess-both prospectively, contemporaneously, and retrospectively - the way we exercise our moral agency (in 'exercises' of moral agency I include our attitudes and the ethical positions we hold/advance, as well as speech, actions, and omissions). As such, to the extent that the practice of healthcare necessarily (and perhaps routinely) involves decisionmaking that contains a moral element (as many writers on conscience have claimed it does $^{4}$ ), the consciences of health professionals will, inevitably, be engaged across a

\footnotetext{
${ }^{3}$ MR Wicclair, 'Is conscientious objection incompatible with a physician's professional obligations?' (2008) 29 Theoretical Medicine and Bioethics 171, 176.

${ }^{4}$ See, eg A Asch, 'Two Cheers for Conscience Exceptions' (2006) 36 Hastings Center Report 11; and D Weinstock, 'Conscientious Refusal and Health Professionals: Does Religion Make a Difference?' (2014) 28 Bioethics 8.
} 
wide range of practice areas. There is extensive scope for overlap between the exercise of conscience in this broad sense, and the exercise of other kinds of judgements that professionals make in the course of their roles, such as judgements about best interests, futility, and any judgement which doesn't simply involve what Miola has called 'technical medical skill'. ${ }^{5}$

$\mathrm{CO}$ is, and ought to be, a much narrower phenomenon, however. Almost all of those who argue that $\mathrm{CO}$ ought to be accommodated within healthcare, myself included, recognise that there must be limits on that accommodation. The debate then becomes one about what the appropriate limits are, and there are various suggestions about how to draw them. One possibility is that we could restrict $\mathrm{CO}$ to a narrow range of treatments. Another is that we can limit $\mathrm{CO}$ according to the nature of the practitioner's potential involvement: for example, allowing professionals to opt out only of 'direct' or 'hands on' involvement, ${ }^{6}$ and perhaps requiring a practitioner who is unwilling to provide a particular treatment to arrange for the patient seeking it to see another practitioner who is willing (the so-called 'duty to refer', sometimes known as the 'conventional compromise'7). Another family of suggestions is that we should only accommodate those objections that pass tests of reasonableness and/or genuineness. ${ }^{8}$ Many writers endorse a combination of these suggestions. In this chapter, I want to make a very specific suggestion: namely, that CO should be accommodated only in relation to a narrow category of activity, which I will call 'liminally proper' medical treatment.

I will begin by describing the spectrum of proper medical treatment and the concept of liminally proper treatment as a category within that spectrum, and will then explain how I think combining this concept with justifications based on 'moral integrity' can help to clarify the proper scope of conscientious objection in healthcare. I will argue that the concept of liminally proper treatment can illuminate some of the key issues in academic debates about conscience. Most importantly, it delineates the

\footnotetext{
5 J Miola, Medical Ethics and Medical Law: A Symbiotic Relationship (Oxford, Hart Publishing, 2007) 13.

${ }^{6}$ Greater Glasgow Health Board v Doogan [2014] UKSC 68.

7 D Brock, 'Conscientious refusal by physicians and pharmacists: who is obligated to do what, and why?' (2008) 29 Theoretical Medicine and Bioethics 187.

${ }^{8}$ See, eg RF Card, 'Reasons, reasonability and establishing conscientious objector status in medicine' (2017) 43 Journal of medical Ethics 222.
} 
range of activities in which $\mathrm{CO}$ should be accommodated: in doing so, it answers questions about the proper scope of CO and whether (and how) CO can be limited, and addresses concerns about so-called 'conscience creep' .9 But it can also help us navigate debates about the reasonableness of conscience claims, and in an overarching sense, the idea of liminally proper treatment also contributes to debates about the compatibility of $\mathrm{CO}$ with healthcare professionalism.

\section{The Spectrum of 'Proper Medical Treatment'10}

The spectrum of proper treatment and the category of liminally proper treatment within it are fundamental to my arguments about $\mathrm{CO}$ throughout this chapter, so it is necessary to set these ideas out thoroughly before going any further.

The phrase 'proper medical treatment' has appeared in case law since at least the second half of the nineteenth century. ${ }^{11}$ In the majority of cases in which it has been used since then, judges have used the phrase simply to denote the treatment that is appropriate for a patient's condition. But in two landmark judgments handed down by the UK House of Lords in early 1993, 'proper medical treatment' was cited (on both occasions by Lord Mustill) in a way that seemed to assign a more substantive, analytical role to the idea. In the first of the two cases, Airedale NHS Trust $v$ Bland,12 Lord Mustill mused:

How is it that ... a doctor can with immunity perform on a consenting patient an act which would be a very serious crime if done by someone else? The answer must be that bodily invasions in the course of proper medical treatment stand completely outside the criminal law. ${ }^{13}$

\footnotetext{
${ }^{9}$ JD Cantor, 'Conscientious objection gone awry: restoring selfless professionalism in medicine' (2009) $360 \mathrm{New}$ England Journal of Medicine 1484, 1485.

${ }^{10}$ The spectrum and categories set out in this section were originally proposed in M Neal, 'Locating Lawful Abortion on the Spectrum of Proper Medical Treatment' in S Fovargue and A Mullock (eds) The Legitimacy of Medical Treatment: What Role for the Medical Exception? (London, Routledge, 2015), 124. The discussion here draws extensively on that earlier analysis, refines it, and applies it to the issue of conscientious objection for the first time.

${ }^{11}$ Symm v Fraser and Another (1863) 3 F\&F 859.

12 [1993] AC 789.

13 ibid at 891.
} 
Just over a month later, in the case of $R v$ Brown, ${ }^{14}$ which concerned sadomasochistic activity between consenting adult men, Lord Mustill enumerated a number of 'special exceptions' to the general rule that consent cannot form a defence to criminal charge of causing actual bodily harm or wounding. One of the exceptions he acknowledged, which was not directly relevant to the case in hand, was 'proper medical treatment':

Many of the acts done by surgeons would be very serious crimes if done by anyone else, and yet the surgeons incur no liability. Actual consent, or the substitute for consent deemed by the law to exist where an emergency creates a need for action, is an essential element in this immunity; but it cannot be a direct explanation for it, since much of the bodily invasion involved in surgery lies well above any point at which consent could even arguably be regarded as furnishing a defence. Why is this so? The answer must in my opinion be that proper medical treatment, for which actual or deemed consent is a prerequisite, is in a category of its own. ${ }^{15}$

In these passages, Lord Mustill understood himself simply to be articulating a 'medical exception' to the criminal law which already existed. As his Lordship observes, such a medical exception is necessary because, although consent can make minor touchings lawful, many of the intrusions that happen in the course of providing healthcare are too significant to be rendered lawful by consent alone; they 'lie well above any point' at which consent could provide a defence. The lawfulness of these more significant intrusions therefore depends upon the operation of the medical exception. Apart from the dicta quoted above, however, the courts' engagement with the medical exception has been minimal; ${ }^{16}$ and apart from a seminal article by Penney Lewis in 2012,17 it was

\footnotetext{
${ }^{14}$ [1994] 1 AC 212.

15 ibid at 266.

${ }^{16}$ In subsequent cases, courts have tended simply to use the phrase or quote Lord Mustill's dicta without any further elaboration. See, eg Ms B v An NHS Hospital Trust [2002] EWHC 429 (Fam); Re A (Children) (Conjoined Twins) [2000]; Secretary of State for Defence v AW [2010] UKUT 317 (AAC); R v BM [2018] 2 Cr App R 1.

17 P Lewis, 'The Medical Exception' (2012) 65 Current Legal Problems 355.
} 
also 'largely overlooked in the medical law literature'18 until it was subjected to sustained scrutiny in a collection of academic essays published in 2015.19 One result of this academic inattention has been that the relationship between 'the medical exception' and 'proper medical treatment' - which is important for the purposes of the present argument-was never clearly explained. Put simply, the landscape of 'proper medical treatment' includes much more than just the serious intrusions that rely on the medical exception for their lawfulness. It also includes many things that are less intrusive - and so are lawful on the basis of consent alone-and others that are not physically intrusive at all, like consultation, visual examination, prescribing, advice, and so on. The relationship between the two concepts might therefore be summarised by saying that the medical exception performs a legitimising function in relation to some but by no means all 'proper medical treatment'.

In my own contribution to the 2015 collection, ${ }^{20}$ my interest was not so much in the operation of the 'medical exception' at the boundary between the lawful and the unlawful, but rather in exploring everything on the 'lawful' side of the line, to see what further distinctions, if any, could be drawn. At the time, I noted that 'little attention seems to have been paid so far to gradations of properness within the landscape of the lawful' ${ }^{21}$ Suspecting that it might be possible to observe various degrees of properness, I began by trying to identify what the features of a 'paradigm case' of proper medical treatment would be, and working from there to identify other categories of treatment which were more or less 'proper' depending on how well they mapped onto that paradigm. Ultimately, I identified three categories within the range of lawful medical treatment: treatment that is paradigmatically proper; treatment that is clearly proper; and treatment that is liminally proper. The latter category, liminally proper treatment, is the one that interests me in terms of its potential for clarifying debates about $\mathrm{CO}$, but it is important to understand how this category is constituted

\footnotetext{
${ }^{18}$ C Purshouse, 'Review of Sara Fovargue and Alexandra Mullock (eds), The Legitimacy of Medical Treatment: What Role for the Medical Exception? London, Routledge, 2016' (2016) 24 Medical Law Review 303, 303. ${ }^{19} \mathrm{~S}$ Fovargue and A Mullock (n 10).

${ }^{20} \mathrm{M}$ Neal (n 10) 124.

21 ibid at 127.
} 
and how it contrasts with paradigm and clear proper treatment before moving on to apply it to $\mathrm{CO}$.

\section{A. Paradigmatically Proper Treatment}

I have argued previously that the paradigm case of proper medical treatment is constituted where 'treatment is carried out with the consent of the patient and for the patient's therapeutic benefit'. ${ }^{22}$ This formulation is an adaptation of Lord Denning's dictum in Bravery $v$ Bravery ${ }^{23}$ that 'ordinary' surgery is 'done for the sake of a man's health, with his consent.'24

There are two distinct elements here: consent, and therapeutic value. Here, 'consent' signifies the consent of the patient herself (and so assumes a patient with capacity). I will use 'therapeutic value' to describe interventions with the potential for health-related benefit, i.e. interventions aimed at the management, care, and/or prevention of disease and disorder. So on what basis can the paradigm case of proper medical treatment be said to comprise these two elements?

Consent belongs in the paradigm, in my view, because of the dominance of the principle of respect for autonomy in medical law and ethics. ${ }^{25}$ The requirement for consent is one of the main ways in which that principle is given effect. Lord Mustill noted in Bland that 'consent is normally an essential element in proper medical treatment' ${ }^{26}$ He elaborated:

[T] he consent of the patient is so important ... because it is usually essential to the propriety of medical treatment. Thus, if the consent is absent, and is not dispensed with in special circumstances by operation of law, the acts of the doctor lose their immunity ... If the patient is capable of making a decision on whether to permit treatment and decides not to permit it his choice must be

\footnotetext{
22 ibid at 128.

${ }^{23}$ [1954] 1 WLR 1169 (CA).

24 ibid at 1180.

${ }^{25}$ TL Beauchamp and JF Childress, Principles of Biomedical Ethics, $4^{\text {th }}$ edn (Oxford, Oxford University Press, 1994).

${ }^{26}$ Airedale NHS Trust $v$ Bland [1993] AC 789, 892 (per Lord Mustill).
} 
obeyed, even if on any objective view it is contrary to his best interests. A doctor has no right to proceed in the face of objection, even if it is plain to all, including the patient, that adverse consequences and even death will or may ensue.

A few weeks later, in Brown, his Lordship referred again to 'proper medical treatment, for which actual or deemed consent is a prerequisite' ${ }^{27}$ The requirement for consent is wide-ranging: it is now well-established in law that an adult patient with capacity has 'an absolute right to choose whether to consent to medical treatment,' 28 and that this right to choose 'exists notwithstanding that the reasons for making the choice are rational, irrational, unknown or even non-existent.' ${ }^{29}$ The requirement is also capable of trumping other important legal and ethical considerations: when a patient has capacity, her autonomy will be respected (as noted in Lord Mustill's dictum above) even where her autonomous choice places her life in danger, ${ }^{30}$ and even where it risks not only her own life, but also the life of a viable foetus. ${ }^{31}$ The fact that consent is indispensable where it is possible indicates that consent is the ideal; the 'gold standard' that we seek wherever possible.

Therapeutic value is also paradigmatic, because of the widespread understanding that healthcare exists to provide health-related benefits to patients. The physician patient relationship has traditionally been regarded as a 'healing relationship',32 and relationships and encounters between health professionals and patients as 'therapeutic' relationships and encounters. ${ }^{33}$ The British Medical Association, for example, refers to the 'normal therapeutic role' of the doctor. ${ }^{34}$ Moreover, while scholars disagree regarding the ends and goals of medicine (and I will return to this theme later), all plausible suggestions seem to cite the provision of health-related benefits. ${ }^{35}$ As Wicclair has noted,

\footnotetext{
${ }^{27} R v$ Brown [1994] 1 AC 212 at 266.

${ }^{28}$ Re T (Adult: Refusal of Medical Treatment) [1992] EWCA Civ 18 per Lord Donaldson (emphasis added).

29 ibid at para 3.

${ }^{30} \operatorname{Re} T$ ( $\mathrm{n} 28$ ); see also the discussion of autonomy trumping sanctity of life in Bland (n 26).

${ }^{31}$ St George's Healthcare NHS Trust v S [1998] 3 All ER 673.

${ }^{32}$ ED Pellegrino, 'Toward a Reconstruction of Medical Morality' (2006) 6 The American Journal of Bioethics 651, passim.

${ }^{33}$ British Medical Association, Medical Ethics Today: The BMA's Handbook of Ethics and Law (Oxford, Wiley, 2012), passim.

34 ibid 690.

${ }^{35}$ See also L Frith, 'What do we mean by “Proper” Medical Treatment?' in S Fovargue and A Mullock (n 10) 32.
} 
it is plausible to maintain that healing is associated with the concept of medicine (or any credible conception of it), and it is arguable that an individual who is not committed to that end fails to qualify as a physician, let alone a virtuous one. ${ }^{36}$

Given all of this, it makes sense to regard treatment provided with the patient's consent and directed at a healing or therapeutic outcome as paradigmatically proper. The majority of treatment falls into this category: whenever a patient with capacity consents to treatment for his/her own benefit, the treatment is paradigmatically proper.

\section{B. Clearly Proper Treatment}

Obviously, a large number of well-accepted healthcare interventions do not correspond to the paradigm just described, and treatment can, of course, still be lawful, and ethical, when one or other element of the paradigm is absent. When consent is impossible because a patient lacks capacity, various patient-focused consent substitutes are possible. Adults with the legal power to do so can give consent on behalf of young children, or other adults who lack capacity; treatment in emergencies can be justified by appeal to the doctrine of necessity; or treatment can be provided on the basis that is in the 'best interests' of a patient with a long-term or permanent incapacity. In a very limited number of cases, the patient-focused consent substitute is the authorisation of a court, ${ }^{37}$ or power granted under legislation. ${ }^{38}$ All of these

\footnotetext{
${ }^{36}$ MR Wicclair (n 3) 174.

37 Court authorisation is required for non-therapeutic sterilisation of patients with incapacity. Where the procedure is therapeutic - for example, to deal with a medical condition such as excessive menstruation or cancer - the relevant patient-focused consent substitute is 'best interests', and no court authorisation is necessary: see J Herring, Medical Law and Ethics, $5^{\text {th }}$ edn (Oxford, OUP, 2014) 281.

${ }^{38}$ In the UK, mental health legislation empowers doctors to treat mentally-ill patients non-consensually in very limited circumstances. This power only applies in relation to treatment of the person's mental disorder itself; it is not a wide-ranging power to treat the patient without her consent. The relevant statutory provisions are in $\mathrm{s}$ 58 of the Mental Health Act 1983 (which allows compulsory treatment in England and Wales on the basis of a 'second opinion' from an appointed doctor who has consulted with professionals involved in the person's
} 
modes of justification, although still patient-centred in the sense that they are concerned with the patient's good, or interests, are nevertheless 'alternative' in the sense of being departures from, or substitutes for, the ideal of informed consent. As such, it is submitted that these are not paradigmatic cases of proper treatment. Nevertheless, it is both necessary and desirable that we be able to intervene therapeutically in cases where patients cannot give their consent. It is desirable, for example, that health professionals be able to treat children with their parents' consent, to perform emergency surgery on a patient who is rushed to hospital while unconscious, or to administer antibiotics to a patient with dementia who has a bacterial skin infection. Therapeutic treatment where consent is impossible but is substituted by another patient-centred safeguard is not subject to serious doubts about whether it is the kind of thing that health professionals should be involving themselves in: although it does not map on to the paradigm of proper medical treatment, therefore, it is nevertheless clearly proper.

\section{Liminally Proper Treatment}

My main focus in this chapter is on a third category - 'liminally proper treatment'. So when is treatment liminally proper? Here, the element of consent is not the issue. I have claimed that where consent is absent, but its absence is compensated by an alternative patient-centred justification (such as necessity or best interests), treatment is clearly proper. If consent is possible, but is not obtained, then any intervention on the patient is improper. ${ }^{39}$ Thus, liminality does not arise because of an issue with the consent element of the paradigm, but rather because of a question mark over the second element of the paradigm: the therapeutic value or therapeutic potential of the intervention.

\footnotetext{
treatment) and Part 7 of the Mental Health (Care and Treatment) (Scotland) Act (which provides for Compulsory Treatment Orders in Scotland).

${ }^{39}$ With the very limited exception of non-consensual treatment under mental health legislation described above in $\mathrm{n}$ 42. Where legislation provides authority, this authority functions as a patient-focused consent substitute and renders treatment 'clearly proper'.
} 
In some liminal cases, the issue is that there is room for disagreement about whether the procedure is genuinely therapeutic (according to the meaning set out above). In these cases, controversy might arise either because it is disputed that the patient's condition is a disease or disorder, or because the proposed treatment is risky or experimental. These sorts of issues arise in relation to what Penney Lewis has called 'new or controversial medical procedures', like 'cosmetic surgery; circumcision and genital mutilation; contraceptive sterilization; organ donation; non-therapeutic research; gender reassignment surgery; and amputation for body integrity disorder' ${ }^{40}$

Abortion is another example of a practice in which therapeutic value is arguably often absent. It has been acknowledged that 'in the vast majority of cases ... the request for abortion is not grounded primarily in medical factors' ${ }^{41}$ but is sought and provided primarily for 'social' reasons. Such abortion must be regarded as liminally proper, on my analysis, due to the question mark over its therapeutic value (I discuss this in more detail later). Questions also arise about therapeutic value in relation to practices like assisted suicide and euthanasia. In these cases, we can reasonably ask whether a life-ending intervention can logically be beneficial, given the lack of a beneficiary (since the person who would have been the beneficiary is extinguished by the intervention). Because this question deserves to be taken seriously, ${ }^{42}$ these practices' potential for health-related benefit is necessarily contestable; this in turn means that the practices, where lawful, are liminally proper.

Thus, the liminal category consists of interventions where the potential for health-related benefit is absent, uncertain, or contested. It also includes some interventions that have been recognised as proper medical treatment although they are positively harmful-either because they harm the patient without any possibility of benefit at all, or because whatever benefit they offer cannot outweigh the harm caused. Living kidney donation is the example that comes most readily to mind: while the intervention on the recipient is obviously therapeutic, the intervention on the donor to remove her organ obviously results in a significant reduction of function and the

\footnotetext{
${ }^{40} \mathrm{P}$ Lewis (n 17) 355.

41 S Sheldon, 'The Abortion Act's Paternalism Belongs to the 1960s' The Guardian (London, 22 March 2012) www.theguardian.com/law/2012/mar/22/abortion-act-needs-reform.

42 I will explore this issue further in future work.
} 
increased health risks associated with having only one healthy kidney. So how does such an intervention come to be regarded as proper treatment, and permitted by law, despite this?

In discussing the medical exception, Penney Lewis observed that when treatment is permitted in spite of absent or contested therapeutic potential for the patient, its authorization involves some kind appeal (explicit or implicit) to 'public good' considerations. As Lewis puts it, '[ $t$ ]he therapeutic intention or intention to benefit the patient may be absent because the intention is to benefit another, or society' ${ }^{43}$ She acknowledges that ' $[\mathrm{t}]$ he public focus of the justification may be implicit or explicit'. 44

It is for those advocating the recognition of a nontherapeutic practice as 'proper treatment' to advance the necessary public interest justification and appeal to the relevant 'public goods', but in the case of living kidney donation, these 'goods' will presumably include altruism and the desirability of saving life; in the case of abortion, arguments include the 'good' of bodily autonomy and the harm of having to remain pregnant against one's will. Arguments for decriminalising assisted suicide and euthanasia often refer to the 'goods' of minimising suffering, being compassionate, and respecting choice/autonomy in relation to intimate decisions. The role of public good claims in bringing non-therapeutic practices and actions within the scope of 'proper medical treatment' is important in terms of the link between liminality and conscientious objection, discussed further below.

\footnotetext{
${ }^{43}$ P Lewis (n 17) 359.

${ }^{44} \mathrm{P}$ Lewis (n 17) 361.
} 
Figure 8.1 The spectrum of proper medical treatment determined by therapeutic value

\begin{tabular}{|c|c|c|c|c|c|c|c|}
\hline \multicolumn{8}{|c|}{ DOES THE INTERVENTION AIM TO PROVIDE A THERAPEUTIC BENEFIT TO THE PATIENT? } \\
\hline \multicolumn{4}{|c|}{ YES } & \multicolumn{4}{|c|}{ NO } \\
\hline \multicolumn{4}{|c|}{ Patient has capacity? } & \multicolumn{4}{|c|}{ Is there a recognised 'public good' justification? } \\
\hline \multicolumn{2}{|c|}{ YES } & \multicolumn{2}{|c|}{ NO } & \multicolumn{3}{|c|}{ YES } & NO \\
\hline \multicolumn{2}{|c|}{ Consents? } & \multicolumn{2}{|c|}{$\begin{array}{l}\text { Is there another patient- } \\
\text { centred justification? }\end{array}$} & \multicolumn{3}{|c|}{ Patient has capacity? } & IMPROPER \\
\hline YES & NO & YES & NO & & & NO & \\
\hline \multirow[t]{3}{*}{ PARADIGM } & IMPROPER & CLEAR & IMPROPER & \multicolumn{2}{|c|}{ Consents? } & IMPROPER & \\
\hline & & & & YES & NO & & \\
\hline & & & & LIMINAL & IMPROPER & & \\
\hline
\end{tabular}




\section{A Central Case: Abortion}

Obviously, abortion is the major context in which the issue of $\mathrm{CO}$ arises, and it was in relation to abortion that I first began to develop my idea of a spectrum of proper treatment. ${ }^{45}$ I argued then that abortion was 'paradigmatically proper' when consent was present and the abortion was performed with the clear purpose of producing a health benefit. Abortion is currently permitted by the law in Scotland, England and Wales on any one or more of the following grounds: 46

A. that the continuance of the pregnancy would involve risk to the life of the pregnant woman, greater than if the pregnancy were terminated; 47

B. that the termination is necessary to prevent grave permanent injury to the physical or mental health of the pregnant woman; 48

C. that the pregnancy has not exceeded its twenty-fourth week and that the continuance of the pregnancy would involve risk, greater than if the pregnancy were terminated, of injury to the physical and mental health of the pregnant woman; 49

D. that the pregnancy has not exceeded its twenty-fourth week and that the continuance of the pregnancy would involve risk, greater than if the pregnancy were terminated, of injury to the physical and mental health of any existing children of the family of the pregnant woman; 50

E. that there is substantial risk that if the child were born it would suffer from such physical or mental abnormalities as to be seriously handicapped;51

\footnotetext{
${ }^{45} \mathrm{M}$ Neal (n 10).

${ }^{46}$ The convention of lettering the statutory grounds A-G is used by the Department of Health \& Social Care in England and Wales and the equivalent reporting body in Scotland when reporting the abortion statistics annually. See, eg Abortion Statistics, England \& Wales: 2017 (Department of Health \& Social Care, 2018). Schedule 1 of the Abortion Regulations 1991 No 499 uses the letters A-E, and Schedule 1 of the Abortion (Scotland) Regulations 1991 No 460 (S41) uses A-G. Grounds A-E inclusive must be certified by two registered medical practitioners, whereas Grounds $F$ and $G$ (the emergency grounds) require certification by a single practitioner.

47 Abortion Act 1967, s 1(1)(c).

48 Abortion Act 1967, s 1(1)(b).

49 Abortion Act 1967, s 1(1)(a).

${ }^{50}$ Abortion Act 1967, s 1(1)(a).

${ }^{51}$ Abortion Act 1967, s 1(1)(d).
} 
F. that the termination is immediately necessary to save the life of the pregnant woman; 52 and

G. that the termination is immediately necessary to prevent grave permanent injury to the physical or mental health of the pregnant woman ${ }^{53}$

Several of these grounds explicitly cite 'health' as the reason for authorising the procedure, and grounds A, B, F, and G seem straightforwardly therapeutic. Nevertheless, not all abortions provided under the Act are necessarily 'therapeutic' in terms of the paradigm I have described. It is difficult to see how an abortion provided only on the basis of ground D or E could be regarded as therapeutic for the woman herself. But there is also a question mark around the therapeutic value of Ground C, the so-called 'social ground', which accounts for upwards of 95 per cent of abortions in the UK, year on year. This ground is also expressed in therapeutic language, but to quote Ann Furedi, CEO of the UK's largest abortion provider, BPAS: '[w]e all know, if we are honest, that ground $\mathrm{C}$ is a kind of code for "it's an unwanted pregnancy"'.54 And as Sally Sheldon, a prominent pro-choice academic, has observed: 'in the vast majority of cases ... the request for abortion is not grounded primarily in medical factors'. 55

In relation to ground $\mathrm{C}$, then, what we seem to have, by abortion providers' and pro-choice campaigners' own account, is therapeutic rhetoric, but a nontherapeutic reality. And if abortion were to be completely decriminalised and made available 'on request' (as is being advocated by campaigners at the time of writing), so that it was no longer being provided even nominally on therapeutic grounds, this would further undermine the link between abortion and therapeutic value.

Significantly, contemporary public debates about abortion contain many claims and counterclaims about the status (or not) of abortion as 'healthcare' or 'treatment'. For example, the campaign to decriminalise abortion in the UK calls for

\footnotetext{
${ }^{52}$ Abortion Act 1967, s 1(4).

${ }^{53}$ Abortion Act 1967, s 1(4).

${ }^{54}$ A Furedi, 'Are there too Many Abortions?' (Winter 2008/9) Special Edition 2 Abortion Review Special Edition: Abortion and Women's Lives (Papers from the BPAS conference, London 25-26 June 2008) 3 www.abortionreview.org/images/uploads/AR_SpecialEdition_2.pdf.

${ }^{55} \mathrm{~S}$ Sheldon ( $\left.\mathrm{n} 41\right)$.
} 
abortion to be regulated 'by the same robust regulatory and ethical frameworks which govern all other medical procedures in the $\mathrm{UK}^{\prime}, 56$ and launching a Home Office review into the desirability of legislating for 'buffer zones' around abortion clinics, the then Home Secretary Amber Rudd said that it is completely unacceptable that anyone should feel harassed or intimidated simply for exercising their legal right to healthcare advice and treatment.' 57 Pro-choice campaigners in the US habitually refer to abortion as 'women's reproductive healthcare',58 and the incoming President of Planned Parenthood Federation of America (the country's largest abortion provider) has recently stated, '[h]aving a physician as the head of Planned Parenthood, it is a sign that what we are doing is mainstream medical care. Why is it not?'59 Conversely, opponents of abortion frequently deny that abortion is healthcare or treatment. To give one recent example, during the recent Eighth Amendment referendum campaign in the Republic of Ireland, a group of general practitioners signed a letter criticising the government's draft abortion legislation in the following terms:

In circumstances where the draft abortion law specifies that the role of the GP will be 'carrying out the termination of pregnancy' at the request of the patient, without the need for any reason to be given by the patient, there is no way such a proposal could be described as 'healthcare'. The government's legislative proposal in the event of the referendum passing would also permit abortion, including on mental health grounds, up to 24 weeks in pregnancy. Again, these vague and ill-defined grounds for abortion do not constitute evidence-based healthcare. 60

\footnotetext{
${ }^{56}$ We Trust Women, 'About the Campaign' at www.wetrustwomen.org.uk/about-the-campaign/.

57 Press Association, 'UK Mulls Tougher Laws to Protect Women from Abortion Clinic Protesters' The Guardian (London, 26 November 2017) at www.theguardian.com/world/2017/nov/26/abortion-clinics-uk-mulls-tougherlaws-to-protect-women.

58 To give just one example, the National Women's Law Center lists 'abortion' under 'Health Care and Reproductive Rights' section on its website at nwlc.org/issue/health-care-reproductive-rights/.

${ }^{59}$ Dr Leona Wen, incoming head of Planned Parenthood, in an introductory video on the organisation's website at www.plannedparenthood.org/about-us/our-leadership/dr-leana-wen.

${ }^{60}$ D Young, '120 GPs sign No Vote Letter Arguing Abortion “without Reason” not Healthcare', Irish News (24 May 2018) at www.irishnews.com/news/republicofirelandnews/2018/05/24/news/120-gps-sign-no-letter-arguingabortions-without-reason-not-healthcare-1338299/.
} 
In light of public disagreement about whether or not abortion is 'treatment', and the non-therapeutic reality of the overwhelming majority of abortions (those provided exclusively on grounds D or E, and almost all of those provided solely on ground C), it seems reasonable to conclude that most abortions can be located within the liminal category of proper medical treatment. The law in the UK already allows CO in relation to these abortions, ${ }^{61}$ while excluding $\mathrm{CO}$ in relation to abortion that is paradigmatically therapeutic (although not explicitly on that basis, of course). ${ }^{62}$ As such, my approach would support accommodating $\mathrm{CO}$ in relation to the same procedures as UK law currently does, albeit for different reasons.

\section{E. An Anomalous Case: Infant Male Circumcision}

Before moving on, I want to note one example that is difficult to categorise on my model: namely, the practice of infant male circumcision (IMC). Opinion is divided regarding whether the benefits of this practice outweigh its risks, ${ }^{63}$ but even among those who accept that it is non-therapeutic, disagreement persists about whether it can be ethical. On the one hand, Margot Brazier writes that '[a]lthough medical opinion may not necessarily regard [IMC] as positively beneficial, it is in no way medically harmful if properly performed.' 64 On the other, Michael Thomson and Marie Fox criticise 'continued professional willingness to tolerate the non-therapeutic, nonconsensual excision of healthy tissue.' 65 If we regard IMC as offering a therapeutic benefit significant enough to justify the intrusion, and if we take the consent of the parents as a valid patient-centred safeguard, then on my model it would appear to be 'clearly proper'. If we regard it as having no therapeutic benefit, however (or not enough to justify the level of intrusion), or as intolerably risky/harmful, then even parental consent ought to be insufficient to bring it even into the liminal category of

\footnotetext{
${ }^{61}$ Abortion Act 1967, section 4(1).

62 Abortion Act 1967, section 4(2).

${ }^{63} \mathrm{M}$ Frisch and BD Earp 'Circumcision of Male Infants and Children as a Public Health Measure in Developed Countries: A Critical Assessment of Recent Evidence,' (2018) 13 Global Public Health, 626.

${ }^{64} \mathrm{M}$ Brazier, Medicine, Patients and the Law (London, Penguin, 1992) 350.

65 M Fox and M Thomson, 'A Covenant with the Status Quo? Male Circumcision and the New BMA Guidance to Doctors' (2005) 31 Journal of Medical Ethics 463.
} 
'proper treatment'. The issue is further complicated by 'public good' claims about IMC's religious significance, the value of respecting religious freedom, and the 'good' of community membership and belonging.

When we compare the example of IMC (understood as non-therapeutic) with the paradigm case of proper medical treatment, we see that in IMC, both elements of the paradigm are being substituted: patient consent is substituted by parental consent, and therapeutic value is replaced with claims about public goods or interests. On my model, where neither element of the paradigm case is present, we are not dealing with proper medical treatment at all. Nevertheless, IMC is lawful in many jurisdictions including the USA (where it is routine for male infants in many parts of the country) and the UK, although there are campaigns to outlaw it in some northern European countries, and a ban is currently being considered in the Danish Parliament. ${ }^{66}$

66 M Busby, 'Danish Parliament to Consider Becoming First Country to Ban Circumcision of Boys', The Independent (3 June 2018) at www.independent.co.uk/news/world/europe/denmark-boyhood-circumcisionpetition-danish-parliament-debate-a8381366.html. 
Figure 8.2 The spectrum of proper medical treatment with examples

\begin{tabular}{|c|c|c|}
\hline & CONSENT OF PATIENT & $\begin{array}{c}\text { OTHER PATIENT/CENTRED } \\
\text { JUSTIFICATION } \\
\text { (BEST INTERESTS, NECESSITY, } \\
\text { CONSENT OF } \\
\text { PARENT/LASTING POWER OF } \\
\text { ATTORNEY) }\end{array}$ \\
\hline $\begin{array}{l}\text { THERAPEUTIC } \\
\text { VALUE FOR PATIENT }\end{array}$ & $\begin{array}{l}\text { PARADIGM } \\
\text { E.g. } \\
\text { - All therapeutic interventions } \\
\text { involving a consenting adult } \\
\text { with capacity }\end{array}$ & $\begin{array}{l}\text { CLEAR } \\
\text { E.g. } \\
\text { - Therapeutic intervention on a } \\
\text { young child or a patient with } \\
\text { dementia } \\
- \text { Emergency surgery on an } \\
\text { unconscious patient } \\
\text { - Court authorised sterilisation of } \\
\text { person with incapacity } \\
- \text { Treatment under mental health } \\
\text { legislation }\end{array}$ \\
\hline $\begin{array}{l}\text { ‘PUBLIC GOOD’’ } \\
\text { JUSTIFICATION }\end{array}$ & $\begin{array}{l}\text { LIMINAL } \\
\text { E.g. } \\
\text { - Living organ donation } \\
\text { - Non-therapeutic abortion }\end{array}$ & $\begin{array}{l}\text { LIMINAL or IMPROPER? } \\
\text { E.g. } \\
\text { - Infant male circumcision }\end{array}$ \\
\hline
\end{tabular}

\section{F. Summary}

Before turning to apply all of this specifically to the context of $\mathrm{CO}$, it is useful to recap what I have claimed so far. My first main claim has been that, although the limited academic literature on proper medical treatment has focused on the operation of the 'medical exception' in drawing a line between the lawful and the unlawful, there is also analytical work to be done in categorizing what lies on the lawful side of that line. Specifically, I have proposed that we understand the landscape of 'proper medical 
treatment' as a spectrum comprising gradations of properness, and I have made a series of claims about how the categories within that spectrum are constituted. In paradigm cases of proper treatment, the patient herself has consented to an intervention that has the potential for therapeutic benefit to her. In clear cases of proper treatment, the therapeutic element of the paradigm is still present, but the consent element is substituted by another patient-centred justification (proxy consent, necessity, or best interests) because the patient lacks capacity and consent is therefore impossible. There is also, I have argued, a liminal zone of proper medical treatment, containing practices or individual cases in which therapeutic value is absent or contested, and where the status of the practice as 'proper' depends instead upon explicit or implicit claims about public good or public interest.

It is not part of my project here to describe the content of the liminal category comprehensively; the content of the category itself will inevitably be contested. However I have already suggested that it might include much abortion, as well as practices like gender reassignment surgery and assisted reproduction for people who are not affected by fertility issues; it will also include assisted suicide and euthanasia wherever these practices are lawful. It must be emphasised that my claim here is not that these practices are not proper; rather, it is that when they are lawful, they occupy a contested realm within the spectrum of what is proper.

Importantly, the content of the liminal category will not remain constant, but will evolve. Emerging treatments that are risky or controversial will become new additions to the category, while other previously-liminal practices will move out of the liminal realm and into the 'clearly proper' category as they become less risky, or as normalisation takes effect. Some activities are likely to remain contested over the long term: 'life issues', for example, or interventions that are perceived to be aimed at preference-satisfaction rather than the management, care, or prevention of disorders. But what counts as liminally proper treatment will develop over time, and on my model, this means that new things will inevitably join the range of practices to which $\mathrm{CO}$ is available, and others will cease to be appropriate contexts for objection. 


\section{Restricting CO to Liminally Proper Treatment}

\section{A. 'Lawfulness' and 'Properness'}

Often, arguments against accommodating CO cite the 'lawfulness' of treatment as a reason why someone employed as a health professional ought to be willing to provide it. Christian Fiala et al, for example, complain that ' $[\mathrm{r}]$ eproductive health care is the only field in medicine where societies accept the argument that the "freedom of conscience" of health care professionals (HCPs) and institutions can limit a patient's access to a legal medical treatment'. ${ }^{67}$ In their view, $\mathrm{CO}$ should really be called 'dishonourable disobedience' because it violates 'the right to lawful healthcare'. ${ }^{68}$ Very recently, Fiala and Joyce Arthur have emphasised law and lawfulness in questioning the permissibility of $\mathrm{CO}$ :

In effect, the state is allowing objectors to personally boycott democraticallydecided laws, usually for religious reasons, without having to pay any price for it. But why should doctors be given a privileged exemption from otherwise valid laws ...? ${ }^{69}$

Similarly, Julie Cantor has insisted that '[p]hysicians should support an ethic that allows for all legal options' and should be prepared to 'cast off the cloak of conscience when patients' needs demand it.'70

It is of the nature of $\mathrm{CO}$ that it is practised in relation to treatments that are lawful because, as Sara Fovargue and I have noted, CO operates 'as a bulwark against expectation, and where a practice is unlawful and there is no expectation that

\footnotetext{
${ }^{67}$ C Fiala et al, 'Yes We Can' (2016) 21 The European Journal of Contraception and Reproductive Health Care 201, 201 (emphasis added).

68 ibid (emphasis added).

${ }^{69}$ C Fiala and JH Arthur, 'There is no Defence for "Conscientious Objection" in Reproductive Health Care' (2017)

216 European Journal of Obstetrics \& Gynecology and Reproductive Biology 254, 255.

${ }^{70}$ JD Cantor (n 9) 1485 (emphasis added).
} 
reasonable HCPs will engage in it, the "shield" of [CO] is unnecessary". ${ }^{71}$ Thus, Daniel Weinstock's description of $\mathrm{CO}$ as a 'claim to be exempted from delivering legal medical services'72 is accurate. What I have tried to show so far in this chapter, however, is that the landscape of 'lawful treatment' is not homogenous; we can recognise gradations of properness within it. Within the category of 'liminally proper treatment' are practices whose status as treatment is debatable, because their therapeutic value is, at best, in doubt and this therapeutic deficit is compensated by appeals to the 'public good' or 'public interest'. But claims about the public good or interest are inevitably contested and negotiable, and insofar as examples of liminally proper treatment are justified by reference to such claims, they adopt that element of controversy.

'Lawful treatment' is not a flat, undifferentiated landscape, but rather a spectrum of categories, and the liminal category is a category in which interventions, although legally permitted, are quite appropriately negotiated, debated, and subject to differences of moral opinion. The fact of legalising or decriminalising a practice obviously does not settle outstanding ethical disagreement; and that disagreement will carry on in a number of settings, not least the professional environment(s) where the lawful but ethically-contested practice is to be carried out.

The approach proposed here offers a response to those who claim that professionals should be willing to provide any treatment that happens to be lawful. It allows us to distinguish different degrees of properness within the range of what is lawful, allowing for different responses to these different degrees of properness. If the status of an intervention as proper treatment is debatable, it is not obvious that all professionals should be willing to perform it.

\footnotetext{
${ }^{71} \mathrm{~S}$ Fovargue and M Neal, 'In "Good Conscience": Conscience-Based Exemptions and Proper Medical Treatment' (2015) 23 Medical Law Review 221, 229.

${ }^{72}$ D Weinstock, 'Conscientious Refusal and Health Professionals: Does Religion Make a Difference?' (2014) 28 Bioethics 8, 12.
} 


\section{B. 'Moral Integrity' as (Insufficient) Justification for CO}

But what about the role of moral integrity in justifying CO? I mentioned earlier that the case for accommodating $\mathrm{CO}$ usually involves arguing that moral integrity is valuable and worth preserving, and that we must allow $\mathrm{CO}$ so that individuals are not forced to violate their moral integrity by sharing in moral responsibility for what they consider to be serious wrongdoing. The view that accommodation of $\mathrm{CO}$ is necessary because of the need to protect integrity has been described as a 'dominant' 73 and 'uncontroversial'74 view in the academic literature on conscience, and I have endorsed the idea of a strong connection between conscience, moral agency and integrity in my own previous work. ${ }^{75}$ But if moral integrity is the ground-level justification for accommodating $\mathrm{CO}$, how does this square with my proposal that we accommodate $\mathrm{CO}$ only in relation to liminally proper treatment, given that the moral integrity of individual professionals may also be at stake in non-liminal cases?

The answer must be that moral integrity alone cannot delimit the extent of permissible CO. Although it seems axiomatic that a genuinely conscientious objection will necessarily involve a wish on the part of the objector to hold the line on a matter she regards as ethically serious, it is frankly impossible to verify that this is so in every case. Moreover, as noted already, although the standard way of justifying $\mathrm{CO}$ is to appeal to moral integrity, this is invariably accompanied by an acknowledgment that $\mathrm{CO}$ cannot be available every time a professional might plausibly claim that her moral integrity is at stake, and that some defensible way of limiting it is necessary. It would be practically impossible-not to mention highly undesirable on professional and ethical grounds - to give professionals a blanket entitlement to opt out of tasks purely by claiming that participation would violate their moral integrity. If $\mathrm{CO}$ is to fit within a workable system of healthcare, instead of representing a fatal stumbling block to

\footnotetext{
${ }^{73}$ C McLeod, 'Taking a Feminist Relational Perspective on Conscience' in J Downie and JJ Llewellyn (eds) Being Relational: Reflections on Relational Theory and Health Law (Vancouver, UBC Press, 2012).

${ }^{74}$ A Giubilini 'Conscientious Objections and Medical Tribunals' (2016) 42 Journal of Medical Ethics 78.

${ }^{75} \mathrm{M} \mathrm{Neal}$ and S Fovargue, 'Conscience and Agent-Integrity: A Defence of Conscience-Based Exemptions in the Health Care Context' (2016) 24 Medical Law Review 544.
} 
such a system, it must operate within certain parameters, and not amount to what Wicclair has called 'conscience absolutism'. ${ }^{76}$

Consider what we might term 'purely moral' objections: objections that involve claims about morality (and perhaps about risks to moral integrity), but make no claims - either explicit or implicit - about the nature of treatment, or healthcare, or the proper role of the health professional. An example of such an objection might be the objection of a doctor, on religious grounds, to examining patients of the opposite sex. This kind of objection stands outside of healthcare, in conflict with it; it does not advance the enterprise of healthcare as a whole. It might be argued that it is worthwhile to accommodate such objections where possible if the challenges they present are outweighed by the benefits of retaining the services of doctors with those religious beliefs. But if we do choose to accommodate the objection for this sort of reason, what we are doing is entering into a trade-off, effectively saying to the objector: 'we will accommodate your objection because although the objection itself does not benefit the enterprise of healthcare in any way (and in fact harms it), we are willing to absorb this harm in order to benefit from your continued employment in other ways'.

By contrast, objections to liminal treatment themselves add value to the enterprise of healthcare. As noted above, liminally proper treatment invites disagreement, and those who exercise $\mathrm{CO}$ are participating in this legitimate disagreement. When $\mathrm{CO}$ relates to treatment in the liminal realm, then, it is not an abrogation or a contradiction of professionalism. On the contrary, a professional who exercises $\mathrm{CO}$ in relation to a liminal practice is participating in the legitimate process of contesting the status of such practices and reaching a conclusion. $\mathrm{CO}$ is one valid way of engaging with the category of liminally proper treatment, and dissent is just as much a contribution to the discussion as is willingness to participate.

Moreover, when we theorise $\mathrm{CO}$ by reference to liminally proper treatment, we locate the practice of $\mathrm{CO}$ within the norms and language of the healthcare professions, and of healthcare law and ethics, referring to concepts, ideas and principles that are intelligible by those who are being asked to respect the objector's position. This is important, because a major anxiety expressed by opponents of $\mathrm{CO}$ is the worry that

\footnotetext{
${ }^{76}$ MR Wicclair, Conscientious Objection in Health Care: An Ethical Analysis (Cambridge, CUP, 2011) Ch 2.
} 
$\mathrm{CO}$ is too subjective; too dependent on private, hidden reasons that may seem idiosyncratic and are often unarticulated and inaccessible to others. The objector is seen as someone deviating from professional standards of behaviour, standing outside the realm of professionalism and its norms, and speaking, if at all, in a foreign language. $\mathrm{CO}$ is seen not as something that pertains to professionalism, but as something that conflicts with it and denies it. ${ }^{77}$ But when we explain $\mathrm{CO}$ by reference to liminally proper treatment, we locate the objector, and $\mathrm{CO}$ as a practice, within the parameters of professional discourse and professional norms, speaking to the professional community in its own language and engaging in the legitimate process of exploring and debating the boundaries of professional activity. Importantly, I am not claiming here that individual objectors do, or should, actually use this kind of language when expressing their objections; but rather, that those who theorise, regulate, and adjudicate $\mathrm{CO}$ should do so.

\section{Some Clarifications}

\section{A. Distinguishing My Approach from Those That Prioritise ‘Professional Values'}

Across the spectrum of academic opinion on $\mathrm{CO}$, arguments about the legitimacy and scope of CO include frequent references to 'professional values', 'values internal to the profession', 'the ends (or goals) of healthcare', and other, similar formulations. At the sceptical end of the spectrum, there are frequent assertions that 'private' or 'personal' values have no place in professional practice and must not be allowed to shape interactions between professionals and their patients. For some, this means that CO should not be allowed at all; see, for example, Schuklenk and Smalling's insistence that there is no moral claim to $\mathrm{CO}$ because professionals must not be permitted 'to

\footnotetext{
77 See, eg R Baker, 'Conscience and the Unconscionable' (2009) 23 Bioethics ii; also J Savulescu (n 1) and JD Cantor (n 9).
} 
subvert the objectives of the professions they voluntarily joined' ${ }^{78}$ Others are willing to tolerate only those objections that correspond to or are consistent with the values of the relevant profession; according to Martha Swartz, for example, ' $[t]$ here should be a presumption against the validity of conscientious objection based on personal, as opposed to professional, values by health care professionals'.$^{79}$

Writers who are less sceptical or even supportive of $\mathrm{CO}$ also attempt to delineate the acceptable scope of $\mathrm{CO}$ by reference to the core values of the profession' 80 or the 'norm of medicine.' 81 Fovargue and I have previously criticised such attempts on various grounds, including that: (i) the ends/goals of medicine are expressed too vaguely to provide any concrete guidance about whether particular practices are compatible with them or not; (ii) there is no clear demarcation between 'personal' and 'professional' values; (iii) even if we could draw such a line, the compartmentalisation of the personal and the professional would be inimical to the very 'personal integrity' that $\mathrm{CO}$ is supposed to safeguard; and (iv) where 'professional values' refers to the ethical guidance drawn up by a professional body for its members, we need to be willing to question the basis on which the body claims its normative authority (and its claims to trump the demands of individual conscience). In relation to the latter point, we wondered whether $\mathrm{CO}$ might be an important tool by which dominant discourses can be critiqued and contested. ${ }^{82}$

So I am unconvinced by 'professional values' accounts of the limits of CO. Yet there are superficial similarities between the claims of some of the writers at the more tolerant end of that spectrum and the approach I am advancing here, making it important that I spell out the distinctions between my proposal and theirs. Zuzana Deans, for example, distinguishes between what she regards as impermissible objections, where 'an individual's views that are external to the pursuit of the

\footnotetext{
78 U Schuklenk and R Smalling (n 1) 3.

79 MS Swartz, "“Conscience Clauses" or "Unconscionable Clauses": Personal Beliefs Versus Professional Responsibilities' (2006) 6 Yale Journal of Health Policy Law \& Ethics 269, 349-350.

80 Z Deans, 'Conscientious Objection in Pharmacy Practice in Great Britain' (2013) 27 Bioethics 48.

81 TC Saad and G Jackson, 'Testing Conscientious Objection by the Norm of Medicine' (2018) 13 Clinical Ethics 9.

$82 \mathrm{M}$ Neal and S Fovargue (n 75) 559-569.
} 
profession prevent her from providing a service', ${ }^{83}$ and permissible objections in which

a professional considers that to provide a certain service or treatment would endanger not only her personal integrity, but also her professional integrity because she is being asked to do something that she sincerely believes the profession is mistaken to support given the fundamental ethos and pursuit of the profession. This type of conflict is important to recognize, and the moral objection should be heard by the profession. ${ }^{84}$

This sounds similar to my claim about the benefit of casting $\mathrm{CO}$ in a language that is intelligible to those who are being asked to respect the objector's refusal to participate; the reference to a sincere belief that the profession is mistaken also seems to come close to (if not to go as far as) my claim that the 'treatment' status of activity in the liminally proper zone is debatable, and a proper subject of professional disagreement. Likewise, while Wicclair acknowledges that the general reason for accommodating claims is the preservation of moral integrity, he attaches the condition that 'an appeal to conscience has significant moral weight only if the core ethical values on which it is based correspond to one or more core values in medicine'. ${ }^{85}$ I have agreed that the 'groundlevel' justification for $\mathrm{CO}$ is the need to respect and protect integrity, but have also argued for restricting its scope to the liminal zone. So how does what I am saying here differ qualitatively from the positions of commentators like Deans and Wicclair?

The key difference is that the limits I advocate refer not to 'core values' (either of the profession or of healthcare/medicine as an enterprise) but to the idea that some lawful treatment is 'liminally proper', which in turn depends specifically on a deficiency in therapeutic benefit and compensation by public good considerations. Instead of looking at the objection and asking whether that is based on values internal or external to healthcare, my approach does almost the converse: it distinguishes a

\footnotetext{
83 ibid (emphasis added).

84 ibid.

${ }^{85}$ MR Wicclair, 'Conscientious Objection in Medicine' (2000) 14 Bioethics 205, 217
} 
category of treatment on the basis that it is ultimately grounded in factors external to healthcare (specifically, in external claims about 'public goods') and regards such treatment as essentially contestable (and open to objection) for that reason.

So, rather than looking to see whether an objection is grounded in some acceptable (to whom?) interpretation of the 'values of the profession' or the 'goals of healthcare' (notions which are inescapably vague), my approach focuses on the much narrower, more muscular, and everyday notion of 'therapeutic benefit' which, although it too can be disputed (as is assumed by the very notion of liminality central to my thesis here), is nevertheless much less abstract and mercurial than the other types of idea. Instead of asking whether a particular refusal proceeds upon a valid or invalid philosophical position, my approach asks whether a particular practice is aimed (or not) at providing therapeutic benefit to patients. If not, and it is permitted instead on the basis of essentially contestable notions of 'public good' or 'public interest', it is reasonable and legitimate for professionals to take (and act upon) the position that they wish not to be involved in it.

\section{B. Distinguishing my Approach from 'Reasonableness' Tests}

Deans argues that 'if a professional does not want to carry out a certain service, she must surely have to give a good account of her reasons for this, and her reasons must be acceptable to the profession' ${ }^{86}$ Schuklenk notes that 'the principle that objectors ought to explain themselves ... is supported by numerous authors' ${ }^{87}$ Notable examples of authors who support subjecting conscience claims to versions of a 'reasonableness test' include Robert Card, Morten Magelssen, and Thomas Cavanaugh. ${ }^{88}$ Although different authors' proposals differ markedly, the general idea is that by deploying such tests, we can weed out indefensible claims, and/or prevent unmanageable

\footnotetext{
${ }^{86}$ Z Deans (n 80) 53 (emphasis added).

${ }^{87} \mathrm{U}$ Schuklenk, 'Conscientious Objection in Medicine: Accommodation Versus Professionalism and the Public Good' (2018) 126 British Medical Bulletin 47, 50.

${ }^{88}$ See, eg RF Card (n 8); M Magelssen, 'When Should Conscientious Objection be Accepted?' (2012) 38 Journal of Medical Ethics 18; and TA Cavanaugh, 'Professional Conscientious Objection in Medicine with Attention to Referral' (2010) 9 Ave Maria Law Review 189.
} 
expansion of the range of practices covered by conscience rights. Card, for example, proposes that professionals be required to explain their conscientious positions to a Medical Conscientious Objection Review Board which will judge their claims according to a standard of what Card calls 'reasonability' (taking into account factors including whether the professional's position is genuine, whether it reflects one of the person's 'core' values, whether it is based on empirical error, whether it causes 'needless and unwarranted harm' to others, and whether it creates a barrier to the timely provision of care in an emergency), and either grant or withhold 'conscientious objector' status.

Such suggestions tend to involve expecting individual objectors to demonstrate the reasonableness of their own particular objections, and this has always seemed problematic to me, for a variety of reasons that Fovargue and I have enumerated elsewhere. In particular, we have expressed concern that such processes might unfairly disadvantage those who are less confident, articulate, or comfortable discussing their religious and moral views with a panel of 'experts' ${ }^{89}$ We also share Jason Marsh's concern that it might be impossible to establish the 'reasonableness' of religious-based positions, in particular, since these are grounded not in reason, but in supernatural beliefs. Furthermore, as Schuklenk points out, adjudicating on the reasonableness or otherwise of religious and moral positions may also conflict with ' $[t]$ he need for the secular state to remain neutral with regard to the validity or otherwise of these ideologies and individual convictions. ${ }^{\prime 90}$ He notes that the courts in the United States-and other jurisdictions-have shied away from engaging in 'reasonableness tests', quoting the US Supreme Court:

What principle of law or logic can be brought to bear to contradict a believer's assertion that a particular act is 'central' to his personal faith? Judging the centrality of different religious practices is akin to the unacceptable 'business of evaluating the relative merits of differing religious claims.' 91

\footnotetext{
${ }^{89}$ S Fovargue and M Neal (n 71) 235-237.

90 U Schuklenk (n 87) 50.

${ }^{91}$ Employment Division, Dept of Human Resources of Oregon v Smith [1990] 494 US 872, 887 per Scalia J, cited in U Schuklenk (n 87) 50.
} 
It seems fairer to individuals, and more manageable for those running health services, to address reasonableness at the level of the practice rather than at the level of the individual. The approach I propose here would identify a category of activity (the liminal zone of proper treatment) within which it is reasonable to disagree, and recognise a right to object to practices that fall within that category, instead of scrutinising the reasonableness of each individual objector/objection. This amounts to a sort of 'built-in reasonableness test'. Since the ground-level justification for allowing $\mathrm{CO}$ is still a concern to preserve moral integrity, my approach also builds in a presumption that objections will be moral in nature, albeit not purely moral in the sense described above in Section III.B. However, my approach does not consider that there is anything to be gained by attempting to ensure in individual cases that the objection is moral, or reasonable, since this would be so easy for unscrupulous objectors to simulate, and yet unduly difficult for genuine, but less well-educated, less confident, or less articulate objectors to prove.

\section{C. 'Liminally Proper': Practice-Level, Case-By-Case, or Both?}

Throughout this chapter, I have focused on the fact that 'liminally proper' status can be determined at the level of whole practices where therapeutic benefit is contested or absent, and debatable claims about the 'public good' are being used-either explicitly or implicitly - to bring the practice within the rubric of 'healthcare' (and perhaps even to make it lawful at all). But might it also be possible to decide that a particular individual intervention is 'liminally proper' because of the circumstances in which it is performed, even though in other circumstances the same intervention might constitute paradigmatically or clearly proper treatment?

Stephen W Smith has argued, in a series of recent articles, that in addition to the more familiar examples involving beginning of life issues, we can also describe as 'conscience claims' those cases where professionals seek to opt out of treating patients 
beyond the bounds of what is meaningfully therapeutic for that patient. ${ }^{92}$ Smith calls these 'bridge too far' cases; cases in which an intervention which might be entirely appropriate in another context is considered to be a 'bridge too far' for a particular patient, given the patient's prognosis and circumstances. Importantly, Smith explicitly distinguishes these cases from cases covered by 'predictable, generalisable rule-based conscientious objection', ${ }^{93}$ and simply proposes that we recognise the claim of the professional to be allowed to opt out of involvement in interventions of this kind as a 'claim of conscience'. 94

It seems uncontroversial to me that 'conscience' (as opposed to CO) is involved in these cases - the practice of healthcare is widely acknowledged to be a profoundly moral enterprise in which the consciences of professionals are engaged at every turn. ${ }^{95}$ But although Smith does not make the claim that these cases involve CO as such, I think his work raises a question which my model must confront: namely, whether liminality (and therefore the permissibility of $\mathrm{CO}$ ) is only determinable at the wholepractice level, or whether it can also be determined on a case-by-case basis.

I have previously suggested that many 'bridge too far' interventions cannot even be liminally proper:

Individual interventions that belong in this category might include burdensome interventions upon dying patients (for example, the resuscitation of a patient who is terminally ill and close to death, or the aggressive treatment of an infection in a dying patient with antibiotics which cause unpleasant side effects. Insofar as such interventions cause suffering which is not outweighed by any meaningful gain in comfort or enhanced life expectancy, they ... may be outside the boundaries of proper medical treatment. ${ }^{96}$

\footnotetext{
${ }^{92}$ SW Smith, 'A Bridge Too Far: Individualised Claims of Conscience' (2015) 23 Medical Law Review 283.

93 ibid at 283.

94 ibid, passim.

${ }^{95}$ See, eg ED Pellegrino, 'Commentary: Value Neutrality, Moral Integrity, and the Physician' (2000) 28 Journal of Law, Medicine \& Ethics 78; see also A Asch ( $\mathrm{n} 4$ ) and D Weinstock (n 4).

${ }^{96} \mathrm{M}$ Neal (n 10) 131.
} 
I say they 'may be' outside the boundaries because arguably, there may be exceptional cases in which these ostensibly-improper interventions may be justified in the patient's best interests: for example, where a dying patient is resuscitated in order to enable a much wished-for last goodbye with a loved one who is known to be on their way to the bedside. Absent such exceptional circumstances, however, interventions that are on balance harmful, and often performed in circumstances where capacity is impaired, would appear not even to be liminally proper, since there appears to be no plausible 'public good' claim to be made in their defence. And if they are straightforwardly improper (ethically impermissible) on my model, there ought to be no question of any expectation that professionals will undertake them, and thus no need for the shield of CO.

But for argument's sake, would it matter if liminality (and so the permissibility of $\mathrm{CO}$ ) could be determined on a case-by-case basis as well as at the whole-practice level? It might matter if the benefits I have claimed for my model are benefits that accrue only if liminality is always determined at the whole-practice level. In discussing reasonableness tests, above, I claimed that it was an advantage of my approach that it was not necessary to determine the reasonableness of each individual objection. Might this particular benefit be diluted if it were also possible to decide liminality and allow for $\mathrm{CO}$ in individual cases? Arguably not: in these cases, too, the determination of 'reasonableness' would be built into the prior decision about whether or not the intervention was, in fact, liminal. And there is another reason why the existence of liminal interventions could have, at most, a limited impact on my model: namely, that the majority of instances of $\mathrm{CO}$ would still involve practices for which it was predetermined that the practice was liminal and that $\mathrm{CO}$ was therefore applicable, like abortion. To be clear, however: most of what Smith calls 'bridge too far' interventions would be improper, not liminally proper, on my model (meaning there would be no need to consider $\mathrm{CO}$ ).

The other benefits I have claimed for my approach — the benefits of explaining $\mathrm{CO}$ by reference to a spectrum of proper medical treatment, theorising it in terms intelligible to the professions, and understanding it as a legitimate professional position instead of 'dishonourable disobedience' - accrue regardless of whether the 
permissibility of $\mathrm{CO}$ is decided at the level of whole practices or individual interventions.

\section{Conclusion}

In this chapter I have described a spectrum of proper medical treatment that includes a category within which the properness of treatment can be regarded as 'liminal' (existing at the boundary of the spectrum of the proper) due to absent/contested therapeutic benefit and explicit or implicit appeal to 'public good' factors. I have argued that it is in relation to practices in this liminal category that $\mathrm{CO}$ ought to be accommodated. The approach proposed here is distinguishable from approaches which seek to delineate the parameters of $\mathrm{CO}$ by citing 'core professional values' or 'the goals of healthcare' (or similar). In addition, insofar as it might be regarded as containing a built-in reasonableness test, I have argued that is preferable to models which impose tests of reasonableness at the individual level.

Whereas lawfulness is an all-or-nothing property, the 'properness' of treatment can be understood as a scalar property, existing on a spectrum. This can help to explain why, contrary to the claims of some critics of $\mathrm{CO}$, not all lawful treatment is necessarily entitled to the same degree of support from health professionals. Practices in the liminal category are legitimately debated, negotiated, and objected to, including by professionals in the context of their professional roles.

Smith has observed that 'conscience must be inward-facing. A decision of conscience is about the conduct of the person claiming conscience. Conscience is about my actions, not the actions of other people' ${ }^{97}$ The primary reason we allow CO is because we accept that it is sometimes necessary for a professional to be able to extract herself from involvement in something she considers to be seriously wrong and thereby protect herself from sharing in moral responsibility for serious wrongdoing (as she sees it). This is what I mean when I say that respect for moral integrity and concern for its preservation is still the 'ground level justification' for CO on my model.

\footnotetext{
${ }^{97}$ SW Smith, 'Individualised Claims of Conscience, Clinical Judgement, and Best Interests', (2018) 26 Health Care Analysis 81 at 83, emphases added.
} 
But whereas conscience may well be inward-facing, conscientious objection is certainly not, or at least not exclusively. It is a public act, a professional position, and an act of participation: participation in debates at and around the boundaries of 'proper medical treatment'. 